\title{
Patriarchy and accumulation on a world scale - revisited (Keynote lecture at the Green Economics Institute, Reading, 29 October 2005)
}

\author{
Maria Mies \\ Faculty of Applied Social Sciences \\ University of Applied Sciences \\ Mainzerstrasse 5, 50678 Cologne, Germany \\ E-mail: mariamies@aol.com
}

\begin{abstract}
Patriarchy and accumulation - revisited' asks why a book, which first appeared in 1986, still finds so much interest today. The answer is that the analysis of that book is still valid, namely that the unpaid work of women in the household, the work of subsistence producers, working in the informal sector and the work of nature constitute the hidden underground of the capitalist world economy and its accumulation model. In this connection, I use the metaphor of an iceberg economy, where the largest part is hidden under the water. I called this devaluation of work then a process of housewifisation. Today, one speaks of precarisation of work. This work, however, is no longer restricted to women but includes men as well. It is the optimal work for capitalism. And most people in the world do this type of work. The problem is that our concept of labour which still refers only to wage labour, does not at all reflect this reality.
\end{abstract}

Keywords: patriarchy; accumulation; capitalism; informal economy; subsistence; globalisation.

Reference to this paper should be made as follows: Mies, M. (2007) 'Patriarchy and accumulation on a world scale - revisited (Keynote lecture at the Green Economics Institute, Reading, 29 October 2005)', Int. J. Green Economics, Vol. 1, Nos. 3/4, pp.268-275.

Biographical notes: Dr. Maria Mies was Professor of Sociology of the Faculty of Applied Social Sciences, University of Applied Social Sciences, Cologne. For five years, she worked as a Lecturer of German at the Goethe Institute in Pune, India. After her return, she wrote her $\mathrm{PhD}$ dissertation on Indian Women and Patriarchy in 1972. Through her study of Indian patriarchy she discovered German patriarchy. From then onwards, she became active in the international women's movement and in various other social movements. She always combined theoretical work with social activism. In 1979, she initiated the programme Women and Development at the Institute of Social Studies in The Hague, Holland, the first of its kind in the world. A number of influential books and articles have made her ideas widely known, e.g., Women the Last Colony (Mies et al., 1988), Patriarchy and Accumulation on a World Scale: Women in the International Division of Labour (Mies, 1986), Ecofeminism (Mies and Shiva, 1993), Women in the World Economy (Mies, 1997) and The Subsistence Perspective: Beyond the Globalised Economy (Bennholdt-Thomsen and Mies, 1999). 


\section{Introduction}

This article explores the journey of discovery of the connections and contradictions between patriarchal exploitation and capitalist exploitation as the foundation for capital accumulation. This connection was discovered by Veronika Bennholdt-Thomsen, Claudia von Werlhof and myself in the course of our feminist research. It also explores the increasing relevance of this position today in the era of neoliberalism and tries to explain the renewed attention this analysis gets. This is so because it helps working people worldwide to understand why their position is getting worse, even in rich countries.

As feminists in the late 1970s and early 1980s of the last century, we focused on several main contradictions. Firstly, the contradiction, that in industrial societies housework was not counted as work, either by capitalist economists or by socialist ones. Henderson (1999) estimated that up to $50 \%$ of all useful products and services are unpaid and largely produced by women. Their worth is about \$US16 trillion, all of which is missing from the GDP of all countries. It does not appear in the GDP, it does not count, as Waring (1998) found in her seminal work Counting for Nothing: What Men Value and What Women are Worth. Waring cited women's productive work, bearing children, mothering, tending a garden, feeding one's family, milking a cow, raising sheep for own use. All these are not counted as economic activities. Economists consider them as free goods, like sunshine or water, which can be appropriated practically without costs. While asking whether Marx had a different notion of this type of labour, I came across his concept of productive labour. He reserved this concept for the mainly male factory worker, the breadwinner who directly produces exchange and surplus values for the capitalist market. Marx considered this worker as the basis for the working class and for class struggle. Housewives were called reproductive workers only, whose task was to reproduce this working class from day-to-day and from generation-to-generation. Housewives apparently did not produce any exchange value, any commodities, any money value, the only value that counts in capitalism.

From this analysis, I proceeded to discover that this invisible labour was indeed the optimal labour for capitalism, because structurally it is free of costs. This I found through my research on the Lace Makers of Narsapur: Indian Housewives Produce for the World Market (Mies, 1980).

Crocheting lace was a home-based industry in South India. Where the women as housewives were not only doing reproductive but the main productive work as well. Huge fortunes were made by the lace traders on the basis of this labour, because they sold this lace in the world market. Here I coined the concept of housewifisation of labour to characterise this type of labour.

But then my friends and myself discovered other types of labour which do not count, namely labour of small scale subsistence farmers, who mainly produce for their sustenance, then the work done in all colonies where people work almost for nothing for the colonial masters, and finally, the production of nature. Does nature also not produce year after year almost for free? (Mies and Shiva, 1993). Hence, we found that the work of women in the household was connected with all these different types of production, which we then called subsistence production. Subsistence production, according to us, constitutes the eternal basis for capital accumulation, be it capitalist or socialist. Without this subsistence production, the so-called free wage labourer would not be able to sell his labour power and produce surplus value. Nor would the capitalist be able to accumulate capital. 
Around that time, the early 1980s, the new micro-electronic technology and automation destroyed millions of factory jobs and caused a deep crisis in the industrialised countries. Gorz (1985) wrote his book with the title Paths to Paradise. His main thesis was that the classical proletarian is dead. Countering his analysis, von Werlhof (1988) wrote her famous article 'The proletarian is dead! Long live the housewife!' published in our book Women the Last Colony.

Although we did not yet know the new terminology, this article marked the turning point towards the analysis of neo-liberal, globalised capitalism. Von Werlhof wrote that it may seem that the pillar of capitalist production, the male proletariat or the working class is vanishing, the housewife and with her a whole spectrum of so-called informal sector workers appears on the scene, namely time-workers, seasonal workers, part-time workers, migrant workers, legalised and illegal ones, child labourers, small subsistence producers, prostitutes, etc. Von Werlhof wrote that this type of housewifised labour would become the normality in future, not only for women, but for men too. Which means that they have to accept wages much below the wage of a normal male wage worker. Like mothers they have to work round the clock, without fixed working hours. Whereas for wage workers, wage and labour conditions are protected by labour laws and tariff contracts, nothing like that exists for the atomised, unorganised informal sector workers. Their wage is often not even a living wage. It is calculated as if all of them still had a breadwinner behind them. Therefore their income, as it is with housewives, is only considered as supplementary to that of a male breadwinner.

Today we have reached the stage when this prediction has come true. These days work in the informal sector appears as the optimal labour for neoliberal capitalism. Because the neoliberals demand that labour laws should be deregulated, that the welfare state should be dismantled, that national borders should be opened globally for the free flow of capital, goods and investment and that government assets should be privatised. This process of transformation was immediately accompanied by a drastic fall of employment everywhere. Many of the unemployed, erstwhile protected wage labourers now became unprotected informal sector workers who had to see how to survive. Even those who still have an apparently secure job in the formal sector, they too are threatened by this type of housewifisation of labour. Today, however, new concepts are appearing on the scene. Instead of housewifisation one speaks of precarious work, or of flexible work. Yet the fact remains, that people need about three such jobs if they want to earn enough money for a living (McJobs). Young people can hardly expect a full time, secure job for the rest of their lives. I suppose that it is this restructuring of labour, that has generated a new interest in my book Patriarchy and Accumulation on a World Scale: Women in the International Division of Labour (Mies, 1986). I visualised this global economy in the form of an iceberg.

\section{The iceberg model of the global economy}

What economists usually call 'The Economy' is only the tip of the iceberg, which consists of capital and labour only, that part which is visible. This visible part counts for the GDP, labour is protected, regulated and organised. Usually there is a contract between the capitalist and the worker. The largest part of this iceberg economy however is below the water. It is invisible, unregulated and unprotected. It is unorganised work and mostly 
without a regular contract. Most of this labour is considered as a 'free good', like nature. A lot of this work is so-called illegal work, like the work of illegal immigrants who nevertheless are needed, for instance as cheap farm workers in Europe.

Figure 1 The iceberg model

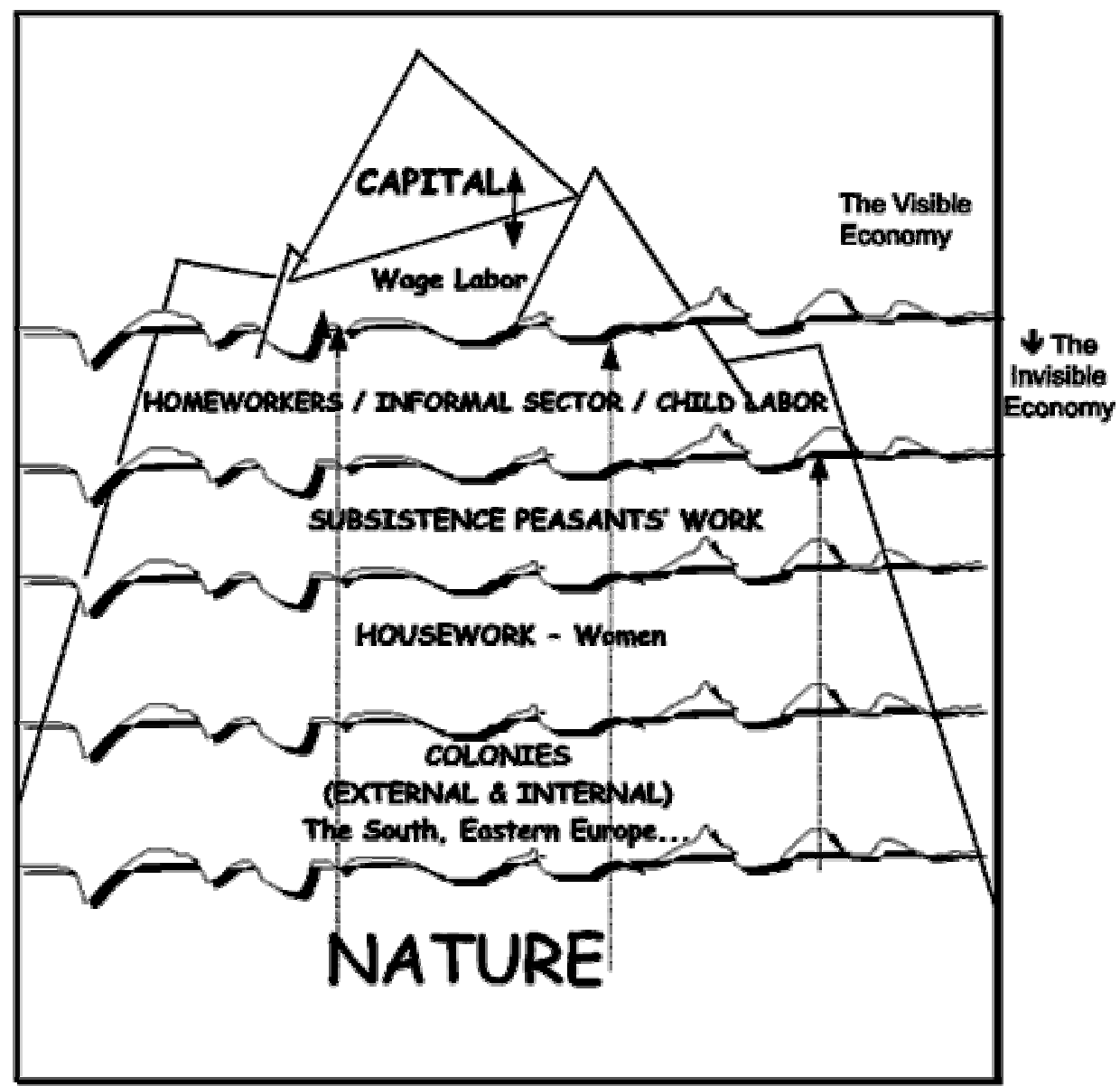

Source: Scott Cato and Kennet (1997) based on Bennholdt-Thomsen and Mies (1999, p.31) and illustration from http://www.jaysquare.com/ resources/workdocs/work06b.htm\#iceberg

Until recently, most of the people under the waterline - the majority of the global workforce - expected that through catch-up development sooner or later they would move up to the higher layers of this capitalist-patriarchal iceberg, up to the level of the protected workers in the industrialised countries at least. But since the beginning of neo-liberal globalisation, even the 'free' wage workers in the formal sector in the rich countries experience the opposite. Millions lose their jobs and fall under the waterline, where they have to join the masses of the precarious workforce in the informal sector. Moreover, they are being told that this will be the normal career for a working person from now on. 


\section{Why patriarchy?}

Although housework is the optimal type of labour under neo-liberal, global conditions, the question still remains whether we can still call this system, capitalist-patriarchal. What are the differences between 1986 and now?

Already in 1986 one could see that the exploitation of young, inexperienced women in the Free Trade or Free Production Zones in the South was not just accidental but belonged to a deliberate capitalist strategy. Meanwhile we know that this is not only the case in countries like Bangladesh or Mexico, but also in so-called socialist countries like Vietnam or China, and even in the rich countries where economists propose to create cheap labour sectors. At the beginning economic growth in China depended largely on the low labour costs of young women in the garment and textile industries. Their exploitation was and is the secret behind most of the cheap clothes we buy in the supermarkets. It is known also that this international division of labour is being accompanied by an enormous increase in male violence against women (Cases: Bangladesh: Throwing acid in the face of women, rape, murder. Mexico: The case of killing young women from the macquilas at the border between Mexico and the USA, e.g., in the city of Juarez). All this is accompanied by a rapid spread of prostitution and trafficking in women all over the globe.

This direct patriarchal violence against women has seen a tremendous increase, particularly during and after the new wars in Yugoslavia, Afghanistan and now in Iraq. There not only foreign troops demand sexual services, but also a whole lot of so-called internationals, ranging from UN to NGO personnel and western businessmen. Prostitution has factually become a new, accepted global service industry, which follows the same rules as other neo-liberal businesses. And it is a growth industry. Not only in war torn areas, but also at the borders between old Europe and the new East European states which have joined the EU, e.g., the Czech Republic, Poland and Ukraine. Patriarchy has been reinforced also in the treaties of the WTO, particularly in the GATS treaty - the General Agreement on Trade in Services. Many of these new services now include women's work in the household. Some feminists say that this is a progressive move since it liberates women from the drudgery of housework. But at a closer look we see that there are mainly women from the South and East, many of them without work permission who now work as the 'new housemaids' for middle class or even working class women in industrialised countries, who then can pursue a career. In any case, these are not signs of liberation, if one woman moves up in the capitalist hierarchy by exploiting another woman. I call this a new type of colonisation. It is also not a sign of emancipation when now prostitutes are called sex workers or free entrepreneurs. These are all patriarchal strategies whose aim is further capitalist growth.

These strategies are all cleverly co-opting concepts and the language of women's liberation and the demands for equality. For many feminists even today, equality is the main goal of women's liberation. They do not demand the end of Patriarchy and Capitalism. In their Plan of Action at the great UN-Women's Conference in Beijing (1995) e.g., they demanded that all governments should introduce programmes of gender mainstreaming. If one looks at the result of this strategy on the backdrop of neo-liberal, global restructuring one cannot see much of an improvement for most women. True, some women have profited from this strategy and have moved up in the Capitalist Iceberg Economy, but mostly at the expense of other women and men. It remains true, that capitalism needs patriarchy to maintain different layers of inequalities and 
exploitability. It cannot afford equality of all, particularly not at the highest level. The new equalisation will therefore be for women and men below the waterline, that means they will become equal as the cheapest workers worldwide. This is the rule of neo-liberal globalisation and universal competition.

This analysis has made clear, I think, that the old strategies and promises of catch up development have failed for good. Particularly if one considers the whole of the global iceberg economy, including nature, all nations, classes and all genders.

Catch up development is not possible for all people, all women and men. Or for all (ex)colonies. It is certainly not good for nature.

\section{From globalisation to localisation}

I have not carried the analysis of the existing capitalist patriarchal world system to its logical conclusion in order to end on a pessimistic note and to leave everybody in depression but rather to destroy the illusion that we can keep the cake and eat it too. If we want to uphold our demand for a humane society and economy for all on a limited earth, we have no alternative but to reject the whole destructive paradigm of the capitalist patriarchal iceberg economy and search for an alternative.

A mere demand to restore the pre-neo-liberal situation, namely the - keynesian welfare state, will not do. We need a much more fundamental change if we want to build a better world in which life is at the centre, women and children and nature, and not money and commodification of everything. We need a real paradigm shift, a new perspective. My friends and myself call it the "Subsistence Perspective" (see Bennholdt-Thomsen and Mies, 1999).

There is no ready-made blueprint for such a society and economy anywhere. Yet, if one looks around one finds a surprisingly large number of persons, groups, organisations, grassroots initiatives and movements who ask the same questions we are asking here, namely:

"What would an economy look like in which nature mattered, in which people mattered, in which women and children and their future mattered, an economy not based on colonizing and exploiting others and the earth for short sighted profit?"

All I can formulate here is a perspective, a vision and some of the main principles of such a perspective. The following changes would be necessary.

\section{Some principles and features of the subsistence perspective}

\subsection{How would work change?}

Change of the sexual division of labour. Men would do as much unpaid work as women. Instead of wage labour independent, self-determined, socially and ecologically useful labour would be at the centre of the economy. Subsistence production would have priority over commodity production. Today subsistence production subsidises the market economy. This must be reversed. Wage labour and the market must subsidise subsistence production. 


\subsection{A new goal for the economy}

The goal of the economy would not be continuous growth and an abundance of commodities in our supermarkets but The Good Life understood as good relations to nature, between men and women, to other people and countries worldwide. This The Good Life for all is possible in smaller, self-reliant communities and regions but not in a globalised economy.

These good relations would be based on reciprocity, mutuality and solidarity. This would imply new and unalienated and closer relations between consumers and producers, rural areas and cities, between different cultures and regions.

\subsection{Changes of concepts of needs and sufficiency}

A new concept of satisfaction of needs follows from a different goal of the economy. It would not be based on an and ever growing mass of often useless commodities which are ecologically and socially destructive. A new subsistence economy would break with the dependence of local and regional areas from a handful of transnational corporations which dictate our needs and supply our satisfiers today. If we want to break this dictatorship over our lives we must turn to voluntary sufficiency and simplicity as precondition for the good life.

\subsection{What are the features of subsistence technology?}

Technology must again become a tool to satisfy needs directly instead of being invented only to enhance capital accumulation. Technology is not systems neutral. The ideology of an epoch is inbuilt in the technology. Some modern high tech is not only useless but also destructive of life (gene-technology, nuclear technology). Most of it was invented as war technology. In a subsistence economy such high tech has no place. Subsistence technology must be able to restore and value scientific and technological knowledge available among the people. It must be such, that its effects are reversible, that they can be repaired and healed.

\subsection{The moral features of a subsistence economy}

The subsistence economy respects the limits of nature everywhere. It cannot be built on any colonisation, internal or external.

The economy has to be re-imbedded into the society as one of its various subsystems. It is not the central and dominant one. This implies the radical critique and rejection of all capitalist and neo-liberal principles, which nowadays have infected all countries and all life: profit-oriented cost benefit principles, universal competition, privatisation of all common property, unfettered liberalisation or deregulation. Communities and states have the duty to serve the common good of all people and not of capital. Such a new Moral Economy is possible only in smaller units, where people can control the economy. It is not possible within a global economy. The global, capitalist economy cannot be humanised, as some think. 


\subsection{Markets and trade in subsistence economies}

Local and regional markets would serve local and regional needs. The primary function of local and regional markets would be to satisfy most of peoples' needs. There would be an exchange of goods between such markets, too. This would preserve the biological and cultural diversity within countries and areas. Such markets would resist global monocultures and monopolies. This does not exclude long distance trade of goods, which are necessary but not available locally. But things that can be produced locally should not be imported from the global market. Trade should follow the principle of subsidiarity.

\section{Money in a subsistence economy}

Money would be a means of circulation, but not a means of accumulation of wealth.

\section{References}

Bennholdt-Thomsen, V. and Mies, M. (1999) The Subsistence Perspective: Beyond the Globalised Economy, London: Zed Books.

Gorz, A. (1985) 'Paths to paradise', On the Liberation from Work, London and Sydney.

Henderson, H. (1999) Small is Beautiful: 25 Years Later with Commentaries, in E.F. Schumacher (Ed.) Vancouver: Hartley and Marks.

Mies, M. (1997) 'Women in the world economy', in M. Scott Cato and M. Kennet (Eds.) Green Economics Beyond Supply and Demand to Meeting People's Needs, Green Audit.

Mies, M. (1980) Lace Makers of Narsapur: Indian Housewives Produce for the World Market, London: Zed Books.

Mies, M. (1986) Patriarchy and Accumulation on a World Scale: Women in the International Division of Labour, London: Zed Books, 1986, 1998 (with a new foreword).

Mies, M. and Shiva, V. (1993) Ecofeminism, London: Zed Books.

Mies, M., Bennholdt-Thomsen, V. and von Werlhof, C. (1988) Women the Last Colony, London: Zed Books.

Von Werlhof, C. (1988) 'The proletarian is dead! Long live the housewife!', Women the Last Colony, London: Zed Books, p.168.

Waring, M. (1998) Counting for Nothing: What Men Value and What Women are Worth, Bridget Williams Books. 